\title{
Fused and spiro nitrogen heterocycles of quinuclidine and its $C$-nucleosides
}

\author{
Hanafi Hassan Zoorob, Wafaa Salama Hamama* and Osama Abd El-Magid \\ Department of Chemistry, Faculty of Science, Mansoura University, Mansoura, ET-35516, Egypt \\ ${ }^{*}$ Corresponding author at: Department of Chemistry, Faculty of Science, Mansoura University, Mansoura, ET-35516, Egypt. Tel.: +20.050.2246254; \\ fax: +20.050.2242388. E-mail address: wshamama@yahoo.com (W.S. Hamama).
}

\section{ARTICLE INFORMATION}

Received: 28 August 2010

Received in revised form: 19 October 2010

Accepted: 04 November 2010

Online: 31 December 2011

\section{KEYWORDS}

\section{Quinuclidinone}

Mannich bases

Ring expansion

C-Nucleosides

Spiro derivative

Quinuclidine sugar

\section{Introduction}

Quinuclidine is a part of the structure of a number of natural physiologically active compounds and synthetic drugs [1-3]. Some functionalized synthetic quinuclidines have also been identified as specific muscarinic agonists with potential in Alzheimer's dementia therapy $[4,5]$. Also, used in the synthesis of higher thermodynamic stability of quinuclidine complexes, as 1-quinuclidine-1-boraadamantane [6]. Moreover a variety of quaternary quinuclidinium salts synthesized via the Menschutkin reaction as $N$-ethoxycarbonylmethyl-quinuclidinium chloride dihydrate, QNBE- $\mathrm{Cl}-2 \mathrm{H}_{2} \mathrm{O}$ and quinuclidine betaine hydrate ( $\mathrm{N}$-carboxymethyl-quinuclidinium inner salt, QNB- $\left.\mathrm{H}_{2} \mathrm{O}\right)[7,8]$. As much as the incorporation of Mannich bases into heterocyclic moieties is known to improve their pharmacological properties $[9,10]$, as well as synthetic potentialities [11-15], it seemed interesting to prepare the Mannich bases of quinuclidin-3-one (1) to investigate their synthetic potentialities. The Menschutkin reaction results in formation of a variety of quaternary quinuclidinium salts. Recently, the structures of $N$-ethoxycarbonylmethylquinuclidinium chloride dihydrate, QNBE-Cl- $2 \mathrm{H}_{2} \mathrm{O},[7,8]$ and quinuclidine betaine hydrate ( $\mathrm{N}$-carboxymethyl-quinuclidinium inner salt, QNB- $\left.\mathrm{H}_{2} \mathrm{O}\right)[7,8]$ were reported.

We reported herein the synthesis of novel heterocycleannulated quinuclidine(1-azabicyclo[2.2.2]octane) and spiro compounds and also ring expansion based on the starting quinuclidine which also reacted with different aldohexose and aldopentose derivatives.

\section{Experimental}

\subsection{Instrumentation}

All melting points were determined on Gallenkamp electric melting point apparatus. Elemental analyses were performed on an ECS 4010 Elemental combustion system at the Microanalytical Unit, Faculty of Science, Cairo University. The FTIR spectra were measured using $\mathrm{KBr}$ disc on a Mattson 5000 FTIR spectrometer. The ${ }^{1} \mathrm{H}$ NMR data were obtained in $\mathrm{CDCl}_{3}$ or DMSO- $d_{6}$ on Varian XL $200 \mathrm{MHz}$ instrument using TMS as internal standard. Chemical shifts were reported in ppm $(\delta)$ downfield from internal TMS and coupling constants were expressed in hertz. Electron impact (EI) Mass spectra were recorded on GC-MS QP-1000 EX. Shimadzu Instrument at $70 \mathrm{ev}$. Reactions were monitored by thin layer chromatography (TLC) using EM science silica gel coated plates with visualization by irradiation with ultraviolet lamp. The starting quinuclidine (1) of code number (Q190-5) was purchased from Aldrich Company.

\subsection{Synthesis}

\subsubsection{4-((3-Oxoquinuclidin-2-yl)methyl)morpholin-4-ium chloride (2) and 1-((3-oxoquinuclidin-2-yl)methyl) piperidinium acetate (3)}

General procedure: A mixture of $\mathbf{1}(0.8 \mathrm{~g}, 5 \mathrm{mmol})$, formalin (6 mmol) and morpholine or piperidine $(5 \mathrm{mmol})$ was refluxed in ethanol $\left(15 \mathrm{~cm}^{3}\right)$ for $8 \mathrm{~h}$ over water bath. After adding few drops of hydrochloric or acetic acids, the precipitate was formed, filtered off, dried and crystallized from ethanol to afford salts of Mannich bases $\mathbf{2}$ and 3, respectively (Scheme 1).

4-((3-Oxoquinuclidin-2-yl)methyl)morpholin-4-ium chloride (2): White crystals. Yield: $15.4 \%$. M.p.: $285^{\circ} \mathrm{C} .{ }^{1} \mathrm{H}$ NMR $\left(\mathrm{D}_{2} \mathrm{O}, \delta\right.$, ppm): 1.8-2.4 (m, $\left.4 \mathrm{H},\left(\mathrm{CH}_{2}\right)_{2} \mathrm{C}\right), 2.66(\mathrm{~m}, 1 \mathrm{H}$, bridgehead), 3.24.2 (complex pattern., $14 \mathrm{H},\left(\mathrm{CH}_{2}\right)_{5} \mathrm{~N}$ and $\left.\left(\mathrm{OCH}_{2}\right)_{2}\right), 5.6(\mathrm{t}, 1 \mathrm{H}$ NCHCO). IR ( $\left.\mathrm{cm}^{-1}\right): 1751$ (CO). MS ( $\left.\mathrm{m} / \mathrm{z},(\%)\right): 224\left(\mathrm{M}^{+}-\mathrm{HCl}\right.$, 4.70\%), 138 (11.0), 137 (21.1), 125 (9.8), 124 (9.4), 123 (15.5), 108 (25.7), 101 (7.4), 100 (32.6), 56 (28.8), 55 (100). Anal. calcd. for $\mathrm{C}_{12} \mathrm{H}_{21} \mathrm{ClN}_{2} \mathrm{O}_{2}$ (260.76): C, 55.27; $\mathrm{H}, 8.12 ; \mathrm{N}, 10.74$ Found: C, 55.41; H, 8.32; N, 10.62\%. 


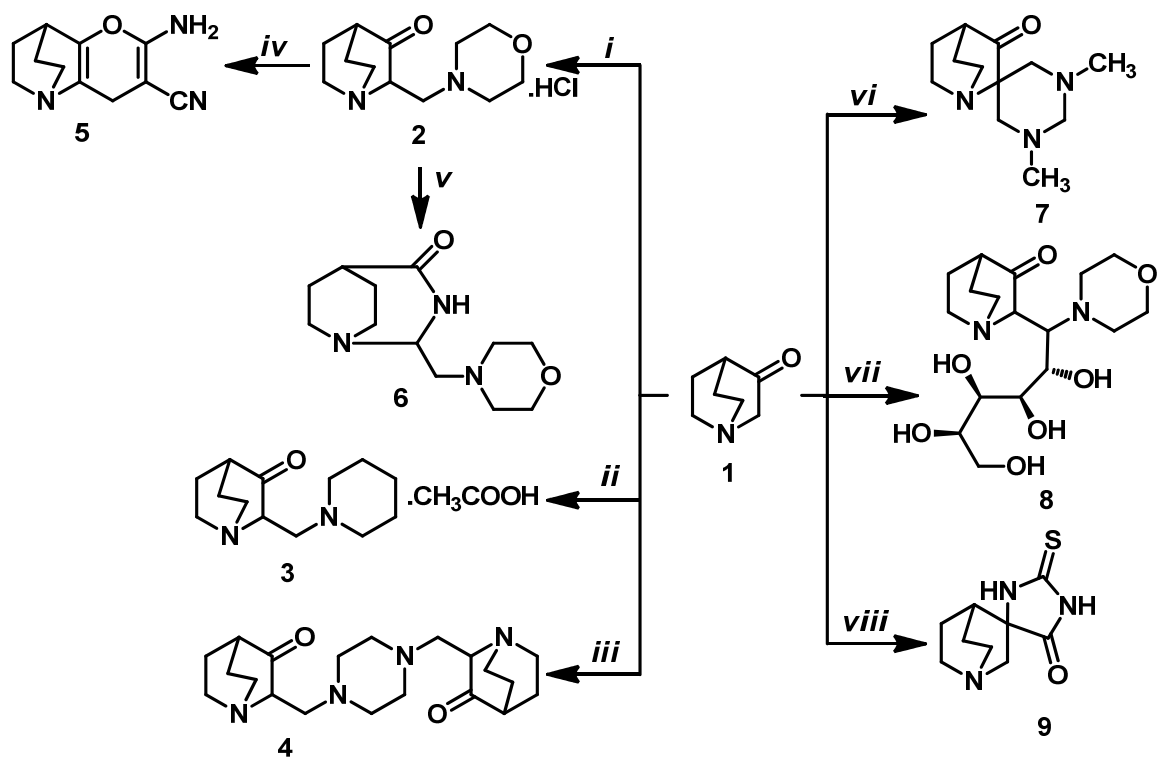

Reaction conditions: $i$, morpholine, formalin (1:1:1.2), $\mathrm{HCl}$; $i$, piperidine, formalin (1:1:1.2), $\mathrm{CH}_{3} \mathrm{COOH}$; iii, piperazine, formalin (2:1:2); $i v$, malononitrile; $v$, sulfuric acid, chloroform, vi, formalin, methylamine (1:20:2); vii, glucose, morpholin; $\mathrm{NaN}_{3}$; viii, aqueous KCN, thiourea.

Scheme 1

1-((3-Oxoquinuclidin-2-yl)methyl)piperidinium acetate (3): White crystals. Yield: $25 \%$. M.p.: $250^{\circ} \mathrm{C}$. IR $\left(\mathrm{cm}^{-1}\right): 1746$ (CO). MS (m/z, (\%)): $222\left(\mathrm{M}^{+}-\mathrm{CH}_{3} \mathrm{COOH}, 0.1 \%\right), 221(0.1), 137$ (19.8), 124 (0.7), 54 (100). Anal. calcd. for $\mathrm{C}_{15} \mathrm{H}_{26} \mathrm{~N}_{2} \mathrm{O}_{3}$ (282.38): C, 63.80; H, 9.28; N, 9.92. Found: C, 63.72; H, 9.31; N, 9.87\%.

\subsubsection{2,2'-(Piperazine-1,4-diylbis(methylene)) bis(quinuclidin-3-one) (4)}

Compound $1(0.8 \mathrm{~g}, 5 \mathrm{mmol})$ was added to a mixture of formalin $(0.2 \mathrm{~g}, 6 \mathrm{mmol})$ and piperazine $(0.46 \mathrm{~g}, 2.5 \mathrm{mmol})$ in ethanol $\left(15 \mathrm{~cm}^{3}\right)$. The reaction mixture was refluxed for $2 \mathrm{~h}$ over water bath. After addition of few drops of concentrated hydrochloric acid, the precipitate was formed, filtered off, washed with ethanol, dried and crystallized from ethanol to give the bis(quinuclidin-3-one) $\mathbf{4}$ as white crystals (Scheme 1). Yield: 51.7\%. M.p.: $274{ }^{\circ} \mathrm{C}$. IR $\left(\mathrm{cm}^{-1}\right): 1745,1750$ (2CO). MS ( $m / z,(\%)$ ): 363 (M+3, 3.8\%), 303 (3.9), 236 (2.7), 235 (2.7), 224 (2.7), 138 (3.5), 125 (3.1), 124 (5.0), 123 (4.5), 112 (3.9), 110 (8.1), 84 (1.2), 82 (10.6), 69 (100). Anal. calcd. for $\mathrm{C}_{20} \mathrm{H}_{32} \mathrm{~N}_{4} \mathrm{O}_{2}$ (360.49): C, 66.63; $\mathrm{H}, 8.95 ; \mathrm{N}, 15.54$. Found: C, 66.72; H, 8.81; N, 15.44\%.

\subsubsection{5-Amino-6-oxa-1-aza-tricyclo[6.2.2.02,7]dodeca-2(7),4- diene-4-carbonitrile (5)}

A solution of Mannish base $2(0.18 \mathrm{~g}, 0.7 \mathrm{mmol})$ in ethanol $\left(10 \mathrm{~cm}^{3}\right)$ and malononitrile $(0.05 \mathrm{~g}, 0.7 \mathrm{mmol})$ heated for deamination [detected by red litmus paper change to blue] then evaporated ethanol under reduced pressure then the reaction mixture was refluxed in dry toluene for $3 \mathrm{~h}$. The reaction mixture was left to stand overnight; after the solvent was evaporated an oily product was obtained which crystallized from ethanol to give $\mathbf{5}$ as brown crystals (Scheme 1). Yield: 42.2\%. M.p.: $205^{\circ} \mathrm{C} .{ }^{1} \mathrm{H}$ NMR ( $\mathrm{CDCl}_{3}, \delta$, ppm): 1.90-2.19 (m, 4H, $\left.\left(\mathrm{CH}_{2}\right)_{2} \mathrm{C}\right), 2.52\left(\mathrm{~s}, 2 \mathrm{H}, \mathrm{NH}_{2}\right), 3.24-3.31(\mathrm{~m}, 5 \mathrm{H}$, bridgehead proton and $\left.\left.\left(\mathrm{CH}_{2}\right)_{2} \mathrm{~N}\right)\right), 4.58\left(\mathrm{~s}, 2 \mathrm{H}, \mathrm{C}=\mathrm{C}-\mathrm{CH}_{2}-\mathrm{C}=\mathrm{C}\right)$. IR $\left(\mathrm{cm}^{-1}\right)$ : $3458,3300\left(\mathrm{NH}_{2}\right), 2236(\mathrm{CN}), 1620(\mathrm{C}=\mathrm{C}), 1381$ (stretching CN). MS ( $m / z,(\%)): 202\left(\mathrm{M}^{+}-\mathrm{H}, 1.3 \%\right), 176(2.5), 175(3.5), 174$ (18.8), 173 (100), 159 (4.6), 158 (23.4), 125 (1.3), 108 (6.4), 94
(14.7). Anal. calcd. for $\mathrm{C}_{11} \mathrm{H}_{13} \mathrm{~N}_{3} \mathrm{O}$ (203.23): C, 65.01; $\mathrm{H}, 6.45$; N, 20.68. Found: C, 64.96; H, 6.38; N, 20.74\%.

\subsubsection{2-Morpholin-4-ylmethyl-1,3-diaza-bicyclo[3.2,2] nonan-4-one (6)}

To a stirred mixture of sulphuric acid $\left(10 \mathrm{~cm}^{3}, 90 \%\right)$ and chloroform $\left(20 \mathrm{~cm}^{3}\right)$ at $0^{\circ} \mathrm{C}$, was added a solution of $2(1.04 \mathrm{~g}, 4$ mmol) in ethanol $\left(5 \mathrm{~cm}^{3}\right)$ followed by addition of sodium azide $(0.26 \mathrm{~g}, 4 \mathrm{mmol})$. The reaction mixture was stirred at $0^{\circ} \mathrm{C}$ for 1 $\mathrm{h}$, then further at $25^{\circ} \mathrm{C}$ for $4 \mathrm{~h}$. It was diluted with ice water basified with ammonia (40\%), then extracted with ether (3x $15 \mathrm{~cm}^{3}$ ); the ether solution was dried on sodium sulphate and evaporated under vacuum to give a solid product which was crystallized from ether/petroleum ether $40-60^{\circ} \mathrm{C}$ to give 6 as white crystals (Scheme 1). Yield: $25 \%$. M.p.: $265^{\circ} \mathrm{C}$. IR $\left(\mathrm{cm}^{-1}\right)$ : 1657 (CO), 3273 (NH). MS: $m / z 241$ (M+2, 75\%), 72 (100). Anal. calcd. for $\mathrm{C}_{12} \mathrm{H}_{21} \mathrm{~N}_{3} \mathrm{O}_{2}$ (239.31): C, 60.22; $\mathrm{H}, 8.85 ; \mathrm{N}, 17.56$. Found: C, $60.41 ; \mathrm{H}, 8.71 ; \mathrm{N}, 17.61 \%$.

\subsubsection{1,4-Ethano-8,10-dimethyl-1,8,10-triaza-spiro[5.5] undecan-5-one (7)}

A solution of $1(0.8 \mathrm{~g}, 5 \mathrm{mmol})$ in ethanol $\left(15 \mathrm{~cm}^{3}\right)$ and formalin $\left(7.5 \mathrm{~cm}^{3}, 100 \mathrm{mmol}\right)$ was heated at $60^{\circ} \mathrm{C}$ for $2 \mathrm{~h}$, then methylamine $(0.45 \mathrm{~g}, 10 \mathrm{mmol}, 33 \%)$ and excess formalin $(0.5$ $\mathrm{cm}^{3}$ ) were added. The reaction mixture was further heated for $3 \mathrm{~h}$. The formed precipitate after cooling the reaction mixture was filtered off, dried and crystallized from ethanol to afford $\mathbf{7}$ as white crystals (Scheme 1). Yield: $35 \%$. M.p.: $240{ }^{\circ} \mathrm{C} .{ }^{1} \mathrm{H}$ NMR (DMSO- $\left.d_{6}, \delta, \mathrm{ppm}\right): 2.04\left(\mathrm{~m}, 4 \mathrm{H},\left(\mathrm{CH}_{2}\right)_{2} \mathrm{C}\right), 2.12\left(\mathrm{~s}, 6 \mathrm{H},\left(\mathrm{CH}_{3}-\mathrm{N}\right)_{2}\right)$, $2.5(\mathrm{~m}, 1 \mathrm{H}$, bridgehead), 3.36-3.39 (complex pattern, 8H, $\left.\left(\mathrm{CH}_{2}\right)_{4} \mathrm{~N}\right), 3.99\left(\mathrm{~s}, 2 \mathrm{H}, \mathrm{N}-\mathrm{CH}_{2}-\mathrm{N}\right)$. IR $\left(\mathrm{cm}^{-1}\right): 1751(\mathrm{CO}) . \mathrm{MS}(\mathrm{m} / \mathrm{z}$, (\%)): $221\left(\mathrm{M}^{+-2}, 0.1 \%\right), 207(0.1), 125$ (18.0), 97 (100). Anal. calcd. for $\mathrm{C}_{12} \mathrm{H}_{21} \mathrm{~N}_{3} \mathrm{O}$ (223.31): C, 64.54; $\mathrm{H}, 9.48 ; \mathrm{N}, 18.82$. Found: C, 64.43; H, 9.59; N, 18.75\%. 


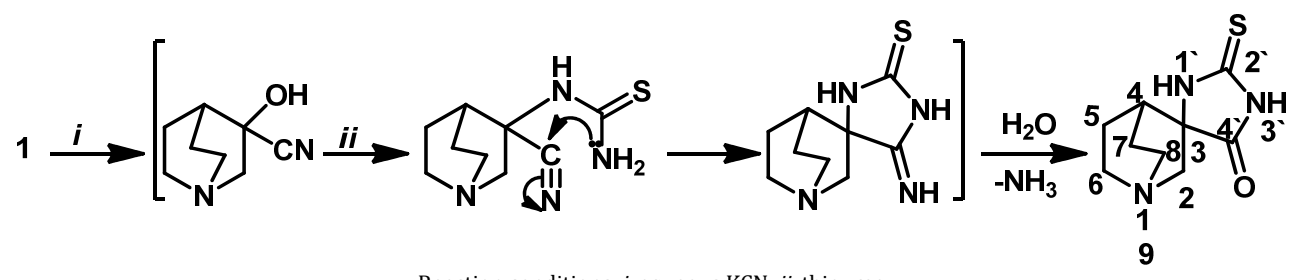

Reaction conditions: $i$, aqueous KCN; $i$, thiourea

Scheme 2

2.2.6. 2-(2,3,4,5,6-Pentahydroxy-1-morpholin-4-ylhexyl)-1aza-bicyclo[2.2.2]octan-3-one (8)

A mixture of morpholine $\left(0.44 \mathrm{~cm}^{3}, 5 \mathrm{mmol}\right)$ and glucose $(0.91$ $\mathrm{g}, 5 \mathrm{mmol})$ in ethanol $\left(10 \mathrm{~cm}^{3}\right)$ was added to a solution of $\mathbf{1}(0.8$ $\mathrm{g}, 5 \mathrm{mmol})$ in ethanol $\left(15 \mathrm{~cm}^{3}\right)$ and the mixture was refluxed for $3 \mathrm{~h}$. After cooling, the formed precipitate was filtered off, dried and crystallized from ethanol to give $\mathbf{8}$ as white crystals. Yield: 42\%. M.p.: $180{ }^{\circ} \mathrm{C}$. IR ( $\left.\mathrm{cm}^{-1}\right): 1751$ (CO), $3369(\mathrm{OH})$. MS (m/z, (\%)): $374\left(\mathrm{M}^{+}, 7.3 \%\right), 158$ (7.4), 125 (18.2), 99 (0.1), 98 (11.2), 97 (50.7), 90 (5.9), 62 (10.5), 55 (100). Anal. calcd. for $\mathrm{C}_{17} \mathrm{H}_{30} \mathrm{~N}_{2} \mathrm{O}_{7}$ (374.43): C, 54.53; H, 8.08; N, 7.48. Found: C, 54.41; $\mathrm{H}, 8.21$; N, 7.51\%.

\subsubsection{7,10-Ethano-2-thioxo-1,3,7-triaza-spiro[5.4]decan-4- one (9)}

A solution of $1(0.5 \mathrm{~g}, 3 \mathrm{mmol}), \mathrm{KCN}(0.195 \mathrm{~g}, 3 \mathrm{mmol})$ and thiourea $(0.228 \mathrm{~g}, 3 \mathrm{mmol})$ in EtOH$/ \mathrm{H}_{2} \mathrm{O}$ mixture $\left(15 \mathrm{~cm}^{3}, 1: 1\right)$ was heated for $48 \mathrm{~h}$, at $60{ }^{\circ} \mathrm{C}$ on water bath. The solvent was evaporated under vacuum and the obtained solid was filtered off, dried and crystallized from ethanol to give $\mathbf{9}$ as pale yellow crystals (Scheme 2). Yield: $55 \%$. M.p.: $162^{\circ} \mathrm{C} .{ }^{1} \mathrm{H}$ NMR (DMSO- $d_{6}$, $\delta, \mathrm{ppm}): 1.99\left(\mathrm{~m}, 4 \mathrm{H},\left(\mathrm{CH}_{2}\right)_{2} \mathrm{C}\right), 2.36(\mathrm{~m}, 1 \mathrm{H}$, bridgehead), 2.96 $\left(\mathrm{m}, 6 \mathrm{H},\left(\mathrm{CH}_{2}\right)_{3} \mathrm{~N}\right), 7.1(\mathrm{~s}, 1 \mathrm{H}, \mathrm{NH})$. IR $\left(\mathrm{cm}^{-1}\right): 3311(\mathrm{NH}), 1736$ (CO), 1087 ( $\mathrm{C}=\mathrm{S})$. MS ( $\mathrm{m} / \mathrm{z},(\%)): 212\left(\mathrm{M}^{+}+1,3.4 \%\right), 135$ (3.9), 88 (3.9), 82 (33), 55 (100), 54 (95.5), 53 (76.8). Anal. calcd. for $\mathrm{C}_{9} \mathrm{H}_{13} \mathrm{~N}_{3} \mathrm{OS}$ (211.28): C, 51.16; H, 6.2; N, 19.89. Found: C, 51.23; H, 6.32; N, $19.93 \%$.

\subsubsection{Reaction of 1-azabicyclo[2.2.2]octan-3-one (1) with sugar molecules: Formation of C-nucleoside derivatives 10, 12-14}

General procedure: A mixture of $1(0.59 \mathrm{~g}, 3 \mathrm{mmol})$ and aldohexsoses or aldopentose $(3 \mathrm{mmol})$ in ethanol $\left(5 \mathrm{~cm}^{3}\right)$ and bidistilled water $\left(0.5 \mathrm{~cm}^{3}\right)$ was heated at $60{ }^{\circ} \mathrm{C}$ for $20 \mathrm{~min}$ on water bath. A catalytic amount of $\mathrm{ZnCl}_{2}$ was added and the reaction mixture was heated till complete dissolution $\mathrm{ZnCl}_{2}$. The reaction mixture was filtered off and left to cool. The formed precipitate was after cooling was filtered off, dried and crystallized from ethanol to yield compounds 10, 12-14 (Scheme 3).

2-Glucopyranosyloxy-1-aza-bicyclo[2.2.2]octan-3-one (10): White crystals. Yield: $43 \%$. M.p.: $160{ }^{\circ} \mathrm{C} .{ }^{1} \mathrm{H}$ NMR (DMSO-d $d_{6}, \delta$, ppm): $2.15\left(\mathrm{~m}, 4 \mathrm{H},\left(\mathrm{CH}_{2}\right)_{2} \mathrm{C}\right), 2.52(\mathrm{~m}, 1 \mathrm{H}$, bridgehead), $3.15(\mathrm{~m}$, $\left.4 \mathrm{H},\left(\mathrm{CH}_{2}\right)_{2} \mathrm{~N}\right), 3.35$ (d, J= 4.0 Hz, 1H, C-CH-N), 3.42-3.55 (m, 3H,

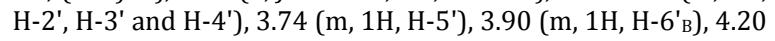
(d, $\left.J=8 \mathrm{~Hz}, 1 \mathrm{H}, \mathrm{H}-6^{\prime}{ }_{\mathrm{A}}\right), 4.6\left(\mathrm{~m}, 4 \mathrm{H}, 4(\mathrm{OH})\right.$, exchangeable by $\left.\mathrm{D}_{2} \mathrm{O}\right)$, 4.9 (d, J= 3.4, 1H, H-1' $\left(\alpha\right.$-linkage)). IR $\left(\mathrm{cm}^{-1}\right): 1746(\mathrm{C}=0), 2971$ (C-H stretching), $3366(\mathrm{OH})$. UV $\left(\mathrm{H}_{2} \mathrm{O}\right) \lambda_{\max }(\log \varepsilon)$ : 194 (2.85), 282 (1.59). MS ( $m / z,(\%)): 287\left(\mathrm{M}^{+}, 6.5 \%\right), 165(0.4), 136(2.2)$, 125 (28.1), 103 (9.4), 97 (100), 96 (49.6), 73 (5.1), 60 (6.5). Anal. calcd. for $\mathrm{C}_{13} \mathrm{H}_{21} \mathrm{NO}_{6}$ (287.31): C, 54.34; $\mathrm{H}, 7.37 ; \mathrm{N}, 4.88$. Found: C, 54.43; H, 7.45; N, 4.94\%.

2-Galactopyranosyloxy-1-aza-bicyclo[2.2.2]octan-3-one (12): White crystals. Yield: 26\%. M.p.: $195^{\circ} \mathrm{C}$. IR $\left(\mathrm{cm}^{-1}\right): 1744$ (C=0),
2980 (C-H stretching), $3392(\mathrm{OH})$. UV ( $\left(\mathrm{H}_{2} \mathrm{O}, \lambda_{\max },(\log \varepsilon)\right): 191$ (2.70), 281 (1.23). MS ( $m / z,(\%)): 284\left(\mathrm{M}^{+}-3,0.7 \%\right), 256(1.9)$, 125 (23.8), 103 (0.9), 97 (100), 96 (57.8), 73 (13.1), 60 (3.8). Anal. calcd. for $\mathrm{C}_{13} \mathrm{H}_{21} \mathrm{NO}_{6}$ (287.31): C, 54.34; $\mathrm{H}, 7.37$; N, 4.88 . Found: C, 54.22; $\mathrm{H}, 7.46 ; \mathrm{N}, 4.86 \%$.

2-Mannopyranosyloxy-1-aza-bicyclo[2.2.2]octan-3-one (13): White crystals. Yield: $35 \%$. M.p.: $230{ }^{\circ} \mathrm{C} .{ }^{1} \mathrm{H}$ NMR (DMSO- $d_{6}, \delta$, ppm): $2.00\left(\mathrm{~m}, 4 \mathrm{H},\left(\mathrm{CH}_{2}\right)_{2} \mathrm{C}\right), 2.50(\mathrm{~m}, 1 \mathrm{H}$, bridgehead), $3.25(\mathrm{~m}$, $\left.4 \mathrm{H},\left(\mathrm{CH}_{2}\right)_{2} \mathrm{~N}\right), 3.35(\mathrm{~d}, J=4.0 \mathrm{~Hz}, 1 \mathrm{H}, \mathrm{C}-\mathrm{CH}-\mathrm{N}), 3.42-3.55(\mathrm{~m}, 3 \mathrm{H}$, H-2', H-3' and H-4'), 3.75 (m, 1H, H-5'), 3.90 (m, 1H, H-6'B), 4.22 $\left(\mathrm{d}, J=8 \mathrm{~Hz}, 1 \mathrm{H}, \mathrm{H}-6^{\prime}{ }_{\mathrm{A}}\right), 4.6\left(\mathrm{~m}, 4 \mathrm{H}, 4(\mathrm{OH})\right.$, exchangeable by $\left.\mathrm{D}_{2} \mathrm{O}\right)$, $4.95\left(\mathrm{~d}, J=3.4,1 \mathrm{H}, \mathrm{H}-1^{\prime}(\alpha\right.$-linkage $)$ ). IR $\left(\mathrm{cm}^{-1}\right): 1744(\mathrm{C}=0), 2982$ (C-H stretching), $3398(\mathrm{OH})$. UV (( $\left.\mathrm{H}_{2} \mathrm{O}, \lambda_{\max },(\log \varepsilon)\right): 191$ (2.95), 194 (2.99), 283 (2.50). MS (m/z, (\%)): $286\left(\mathrm{M}^{+}-\mathrm{H}, 0.5 \%\right), 163$ (0.5), 161 (5.4), 133 (1.6), 125 (100), 103 (0.6), 96 (7.0), 73 (5.4), 60 (4.6). Anal. calcd. for $\mathrm{C}_{13} \mathrm{H}_{21} \mathrm{NO}_{6}$ (287.31): C, 54.34; $\mathrm{H}$, 7.37; N, 4.88. Found: C, 54.27; H, 7.31; N, 4\%.92.

2-Arabinopyranosyloxy-1-aza-bicyclo[2.2.2]octan-3-one (14): White crystals. Yield: 55\%. M.p.: $138{ }^{\circ} \mathrm{C}$. IR $\left(\mathrm{cm}^{-1}\right): 1744$ (C=0), 2982 (C-H stretching), $3437(\mathrm{OH}) . \mathrm{UV}\left(\left(\mathrm{H}_{2} \mathrm{O}, \lambda_{\max }\right.\right.$, (log $\varepsilon)$ ): 195 (2.76), 252 (1.80), 257 (184), 262 (1.78), 280 (1.55). MS $(\mathrm{m} / \mathrm{z},(\%)): 258\left(\mathrm{M}^{+}+1,38.5 \%\right), 257\left(\mathrm{M}^{+}, 35.4\right), 256\left(\mathrm{M}^{+}-\mathrm{H}\right.$, 31.3), 240 (33.3), 229 (37.5), 133 (35.4), 126 (33.3), 104 (39.6), 97 (37.5), 96 (33.3), 73 (45.8), 60 (100). Anal. calcd. for $\mathrm{C}_{12} \mathrm{H}_{19} \mathrm{NO}_{5}$ (257.28): C, 56.02; H, 7.44; N, 5.44. Found: C, 56.12; $\mathrm{H}, 7.51 ; \mathrm{N}, 5.32 \%$.

2.2.9. Acetic acid 4,5-diacetoxy-6-acetoxymethyl-2-(3-oxo-1aza-bicyclo[2.2.2]oct-2-yl)-tetra-hydro-pyran-3-yl ester (11)

Compound 10 (0.72 g, $2.5 \mathrm{mmol})$ was refluxed in acetic anhydride/glacial acetic acid $\left(15 \mathrm{~cm}^{3}, 1: 1\right)$ mixture for $2 \mathrm{~h}$, and left to cool whereby a white precipitate was formed. The product was filtered off, dried and crystallized from ethanol to give $0.91 \mathrm{~g}$ of $\mathbf{1 1}$ as white crystals (Scheme 3). Yield: 80\%. M.p.: $190{ }^{\circ} \mathrm{C}$. IR ( $\mathrm{cm}^{-1}$ ): 1710 (CO, acetate), 1740 (CO), 2970 (C-H, stretching). MS (m/z, (\%)): $454\left(\mathrm{M}^{+}-\mathrm{H}, 0.5 \%\right), 240(0.6), 171$ (0.6), 170 (0.8), 167 (0.9), 161 (0.7), 137 (1.1), 124 (0.7), 104 (0.6), 96 (1.2), 73 (1.5), 52 (100). Anal. calcd. for $\mathrm{C}_{21} \mathrm{H}_{29} \mathrm{NO}_{10}$ (455.45): C, 55.38; H, 6.42; N, 3.10. Found: C, 55.42; H, 6.36; N, $3.18 \%$.

2.2.10. 1,2,3,4,5,6,7,8-Octahydro-9-(1,2,3,4,5-pentahydroxy1-pent-1-yl)-10-oxa-1,8-diaza-1,4,5,8-diethanoanthracene (15)

A mixture of $1(0.8 \mathrm{~g}, 5 \mathrm{mmol})$ and D-glucose $(0.9 \mathrm{~g}, 5$ mmol) in sodium carbonate solution $\left(15 \mathrm{~cm}^{3}, 4 \%\right)$ was heated at $90{ }^{\circ} \mathrm{C}$ for $6 \mathrm{~h}$. The reaction mixture was cooled, and then acidified with dilute acetic acid. The obtained solid product was filtered off, dried and crystallized from ethanol to give $\mathbf{1 5}$ as white crystals (Scheme 3). Yield: $62 \%$. M.p.: $>290^{\circ} \mathrm{C}$. IR $\left(\mathrm{cm}^{-1}\right)$ : 1602 (C=C), 2961 (C-H, stretching), $3395(\mathrm{OH})$. MS ( $\mathrm{m} / \mathrm{z},(\%))$ : $394\left(\mathrm{M}^{+}, 60 \%\right), 107$ (51.4), 73 (48.6), 62 (82.9), 58 (65.7), 56 (90), 55 (100). Anal. calcd. for $\mathrm{C}_{20} \mathrm{H}_{30} \mathrm{~N}_{2} \mathrm{O}_{6}$ (394.46): C, 60.98; $\mathrm{H}$ 7.67; N, 7.1. Found: C, 60.71; H, 7.72; N, 7.32\%. 


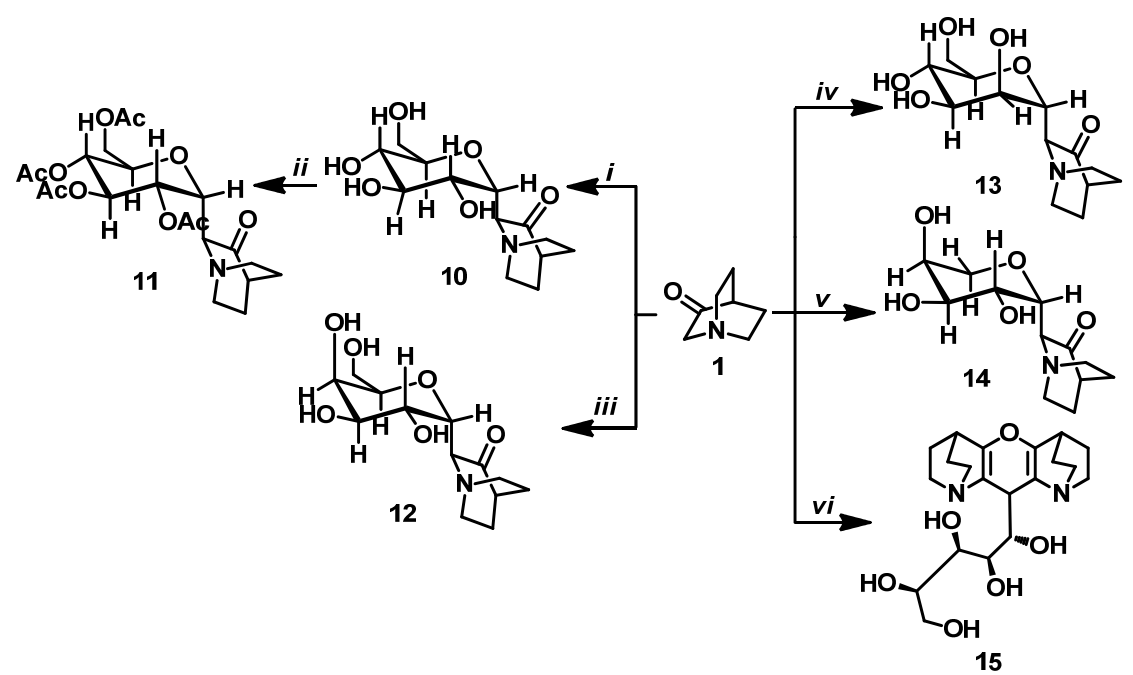

Reaction conditions: $i$, D-glucose, $\mathrm{ZnCl}_{2}$; ii, acetic anhydride, acetic acid; iii, D-galactose, $\mathrm{ZnCl}_{2} ; i v$, D-mannose, $\mathrm{ZnCl}_{2}$; $v$, L-arabinose, $\mathrm{ZnCl}_{2}$; vi, D-glucose, $\mathrm{Na}_{2} \mathrm{CO}_{3}$.

Scheme 3

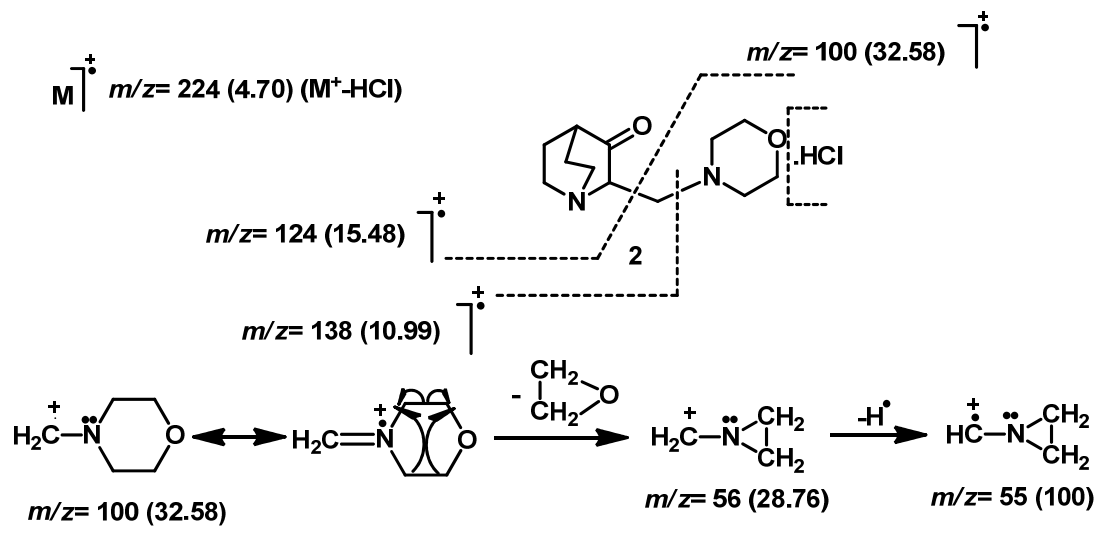

Scheme 4

\section{Results and discussion}

The target compounds were synthesized as outlined in Schemes 1-6. In light of the aforementioned importance of ketonic Mannich bases as precursors for the synthesis of heterocycle-annulated quinuclidine(1-azabicyclo[2.2.2]octane) derivatives, therefore compound $\mathbf{1}$ was subjected to Mannich reaction with morpholine, piperidine and formalin in a molar ratio (1:1:1.2) to afford salts of the Mannich bases 2 and 3, respectively, which were reported as free bases [16]. In addition, the interesting pharmacological activity of piperazine derivatives [17-19], prompted us to prepare 1,4-bis(4-ylmethyl-1-aza-bicyclo[2.2.2] octane-3-one)piperazine (4) through the reaction of $\mathbf{1}$ with piperazine and formalin in a molar ratio of (2:1:2) (Scheme 1).

Formulation of structures 2-4 was based on elemental analysis, IR and ${ }^{1} \mathrm{H}$ NMR spectra. In addition the mass fragmentation pattern of $\mathbf{2}$ showed a good agreement with its proposed structure. Cleavage of the side chain led to fragment at $m / z 138(11 \%)$ characteristic to 2-methylenequinuclidin-3one. Also cleavage of the side chain at the $\beta$-bond led to strong peak at $m / z 100$ which is due to $\left[\mathrm{CH}_{2} \mathrm{~N}^{+}\left(\mathrm{CH}_{2} \mathrm{CH}_{2}\right)_{2} \mathrm{O}\right]$ fragment and the base peak at $m / z 55$. This peak is probably due to fragmentation of the morpholinomethylene (Scheme 4).

Ketonic Mannich bases are of considerable importance as versatile precursors in the synthesis of heterocycles [20-22]. With a view to effect a "one-pot" C-alkylation and cyclization of the Mannich base 2, the reaction of 4-((3-oxoquinuclidin-2yl)methyl)morpholin-4-ium chloride (2) with malononitrile in refluxing toluene was implemented to give 2-amino-3cyanoquinuclidino[3,2-b] pyran(5-amino-6-oxa-1-aza-tricyclo [6.2.2.0 2,7]dodeca-2(7),4-diene-carbonitrile) (5). Its structure was supported by elemental and spectral data. Presumable the formation of $\mathbf{5}$ proceeds via deamination of the Mannich base $\mathbf{2}$ to form 2-methylenequinuclidine-3-one which undergoes thermal Micheal addition of the acidic methylene group of malononitrile followed by nucleophilic addition of enolic $\mathrm{OH}$ group to the carbon atom of cyano group (Scheme 5).

When compound $\mathbf{2}$ was treated with sodium azide in presence of sulfuric acid under Schmidt condition gave the 1,3diazepine derivative 6 as bridged diazepine anchored $\mathrm{N}$-morpholinomethyl side chain. 

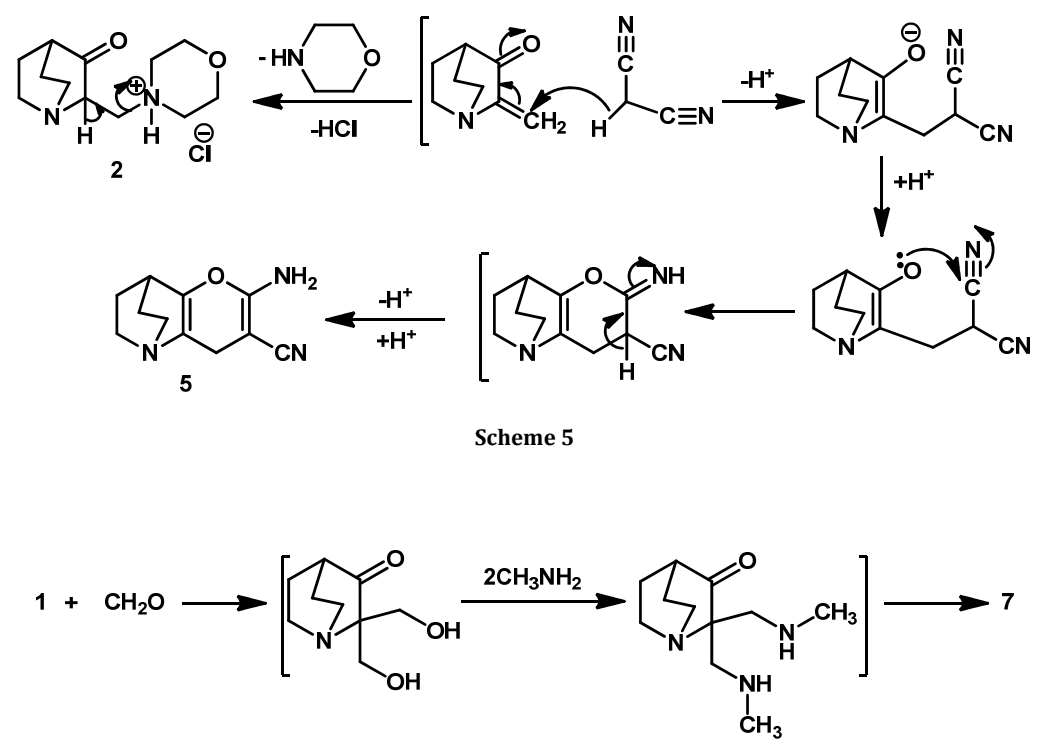

Scheme 6

This method can be considered as alternate route to obtain 1,3-diazepine derivatives which incorporate $\mathrm{N}$-basic side chain at $\mathrm{C}-2$ of the diazepine nucleus since the direct condensation of 1,3-diazepine with formaldehyde gave the $\mathrm{N}$-bis compound. Formulation of structure $\mathbf{6}$ was proved in light of its elemental analysis, IR and mass spectral data. Its mass spectrum added further support to the assigned structure, as it revealed the molecular ion peak at $m / z 239\left(\mathrm{M}^{+}, 75 \%\right)$.

The quinuclidine nucleus is the core component of the cinchona alkaloids, a family of natural products, which not only exhibited antimalarial activity but also found to be widespread use in numerous asymmetric transformations [23-27], and pyrimidine derivatives from bridged alicyclic ketones act as dihydrofolate reductase inhibitor [28]. Consequently, 1 was transformed with a mixture of formalin and methylamine in molar ratio (1:20:2) under Mannich conditions to afford 1,4ethano-8,10-dimethyl-1,8,10-triaza-spiro[5.5]undecan-5-one (7) as spiro compound. It was probably formed through the formation of the intermediate 2,2-bis-methylol-3quinuclidinone followed by amination with methylamine, then by subsequent cyclization with excess of formalin (Scheme 6). This mechanism was supported by the work of Nielsen [29] [via formation of the intermediate 2,2-bis-methylol-3quinuclidinone. Formulation of structure 7 was proved in light of its elemental analysis, IR, ${ }^{1} \mathrm{H}$ NMR and mass data. In addition the Mannich base analogue $\mathbf{8}$ was synthesized by treatment of 1 with glucose and morpholine under Mannich reaction conditions (Scheme 1).

A series of spirohydantoins [30,31], were reported as compounds have several pharmacological activities [32,33]. Therefore, we synthesized spirothiohydantoin 9 for the sake of improving pharmacological potency of quinuclidine. Hence, quinuclidinone $\mathbf{1}$ was transformed by potassium cyanide and thiourea in ethanol into $\mathbf{9}$. The reaction pathway was proceeded via cyanohydrin intermediate [34], followed by condensation with thiourea to furnish compound 9 (Scheme 2). The structure of 9 was proved by its IR, ${ }^{1} \mathrm{H}$ NMR and mass spectra. The IR spectrum of 9 revealed a broad band in the 2500-2800 $\mathrm{cm}^{-1}$ region, similar to the absorption formed in other azabicyclospirohydantoins [35], this absorption is explained by the existence of an intermolecular hydrogen bond which is formed between the weak acid N-3`H group and the basic 1-aza-bicylco[2.2.2] octane nitrogen atom. The $\mathrm{N}-1{ }^{`} \mathrm{H}$ stretching vibration originates a band in the $3311 \mathrm{~cm}^{-1}$ region.
The carbonyl region shows a very strong band at $1736 \mathrm{~cm}^{-1}$; and also strong band at $1087 \mathrm{~cm}^{-1}$ characteristic for $\mathrm{C}=\mathrm{S}$. This interpretation is supported by studies carried out on other azabicyclo-spirohydantoins [36].

The discovery of $C$-nucleosides and their antibacterial and antitumor properties [37-40], and also electrophilic $C$ glycosylation of electron rich aromatic and the heterocyclic systems is widely found in nature [37-40]. Therefore, our attention was directed to the development of synthetic routes to this class of compounds. Surprisingly, a facile synthesis of $C$ nucleoside derivatives of quinuclidin-3-one (1) was achieved by the reaction with different aldoses. In this method, the reaction of 1 with D-glucose was conducted in absolute ethanol at $60{ }^{\circ} \mathrm{C}$ for $20 \mathrm{~min}$. in the presence of catalytic amount of zinc chloride to give the cyclic $C$-nucleoside analogue 10 . In a similar way, the reaction of the hexoses, e.g., D-galactose and Dmannose, and the pentoses, L-arabinose with 1 gave 2-(aldilol1-yl)quinuclidin-3-ones 12-14 (Scheme 3).

The acetylation of $\mathbf{1 0}$ was implemented using acetic anhydride and acetic acid mixture with subsequent dehydration to give the acetylated $C$-nucleoside 11. The mass spectrum of 11 showed the molecular ion peak at $m / z 454\left(\mathrm{M}^{+-}\right.$ $\mathrm{H}, 0.51 \%)$.

Formulation of structure $\mathbf{1 0}$ was based on elemental analysis, IR, UV, ${ }^{1} \mathrm{H}$ NMR and mass spectral data. The coupling constant of the anomeric proton was $3.4 \mathrm{~Hz}$ indicated the $\alpha$ configuration of the glucose moiety. Its mass spectrum showed the molecular ion peak at $m / z 287\left(\mathrm{M}^{+}, 6.5 \%\right)$.

On the other hand, condensation of $\mathbf{1}$ with D-glucose in sodium carbonate as a basic catalyst instead of zinc chloride afforded the bis-quinuclidine sugar 15. Its structure was confirmed by elemental analysis and mass spectrum. Its mass spectrum showed the molecular ion peak at $m / z 394\left(\mathrm{M}^{+}\right.$, $60 \%)$.

\section{References}

[1]. Shvedov, V. I.; Vasileva, V. F.; Korsakova, I. Ya.; Galitsina, V. A.; Medvedev, B. A.; Novitskaya, N. A.; Lapaeva, N. B.; Pershin, G. N.; Mashkovskii, M. D. Khim. Farm. Zh. 1980, 14(8), 38-43.

[2]. Ferri, D.; Buergi, Th.; Baiker, A. J. Chem. Soc. Perkin Trans 2 2002, 437441.

[3]. Baker, R.; Street, L. J.; Reeve, A. J.; Saunders, J. J. Chem. Soc. Chem. Commun. 1991, 11, 760-762. 
[4]. Ashwood, M. S.; Gibson, A. W.; Houghton, P. G.; Humphrey, G. R.; Roberts, D. C.; Wright, S. H. B. J. Chem. Soc., Perkin Trans. 1 1995, 6, 641-644.

[5]. Kaszynski, P.; Pakhomov, S.; Gurskii, M. E.; Erdyakov, S. Y.; Starikova, Z. A.; Lyssenko, K. A.; Antipin, M. Y.; Young, Jr., V. G.; Bubnov, Y. N. J. Org. Chem. 2009, 74, 1709-1720.

[6]. Dega-Szafran, Z.; Katrusiak, A.; Szafran, M. Polish J. Chem. 2009, 83, 723-735

[7]. Dega-Szafran, Z.; Katrusiak, A.; Szafran, M. J. Mol. Struct. 2009, 921, 295-299.

[8]. Azam, Md. A.; Ahmed, N.; Srinivas, S.; Suresh, B. J. Inst. Chem. (India) 1996, 68, 10-12

[9]. Dlugosz, A. Pharmazie 1987, 42 (6), 381-383.

[10]. Chawla, H. P. S.; Gautam, B. C.; Kapil, R. S.; Anand, N.; Patnaik, G. K.; Vohra, M. M.; Shrivastava, O. P. J. Med. Chem. 1970, 13, 480-488.

[11]. Edwards, M. L.; M. L. Edwards, H. W. Ritter, D. M. Stemerick, K. T. Stewart J. Med. Chem., 1983, 26, 431-436.

[12]. Pandeya, S. N.; Sriram, D.; Nath, G.; clercq, E. De Il Farmaco 1999, 54, 624-628.

[13]. Tramontini, M. Synthesis 1973, 12, 703-705.

[14]. Tramontini, M.; Angiolini, L. Tetrahedron 1990, 46, 1791-1837.

[15]. Hansen, A. R.; Bader, H. J. Heterocycl. Chem. 1966, 3(1), 109-109.

[16]. Taylor, E. D.; Nobles, W. L. J. Am. Pharm. Assoc. Sci. Ed. 1960, 49, $317-$ 319.

[17]. Abdel-Rahman, R. M. Il Farmaco 1991, 46, 379-389.

[18]. Abdel-Hamide, S. G. Chem. Papers 1995, 49, 142-148.

[19]. Blicke, F.; McCarty, F. J. Org. Chem., 1959, 24, 1379-1380

[20]. Mannich, C.; Reichert, B. Arch Pharm. 1933, 271, 116-127.

[21]. Schmid, H. J.; Hunger, A.; Hoffmann, K. Helv. Chim Acta 1956, 39, 607 618.

[22]. O'Neil, I. A.; Wynn, D.; Lai, J. Y. Q. Tetrahedron Lett. 2000, 41, 271-274.

[23]. Dehmlow, E. V.; Wagner, S.; Müller, A. Tetrahedron 1999, 55, 63356346

[24]. Lygo, B.; Wainwright, P. G. Tetrahedron Lett. 1998, 39, 1599-1602.

[25]. Corey, E. J.; Xu, F.; Noe, M. C. J. Am. Chem. Soc., 1997, 119, 1241412415.

[26]. Hoffmann, H. M. R.; Plessner, T.; Riesen, C. Synlett. 1996, 7, 690-692.

[27]. Rosowsky, A.; Papoulis, A. T.; Queener, S. F. J. Heterocyclic Chem. 1999, 36, 723-728.

[28]. Nielsen, A. T. J. Org. Chem. 1966, 31, 1053-1059.

[29]. Trigo, G. G.; Martinez, M.; Galvez, E. J. Pharm. Sci. 1981, 70, 87-89.

[30]. Phillips, E.; Mack, R.; Macor, J.; Semus, S. US Patent 1972, 3,681,363; Appl. 1970, 65,773; Chem. Abstr. 1973, 77, 140071p.

[31]. Faust, J. A.; Jules, L. H.; Yee, L.; Sahyun, M. J. Am. Pharm. Assoc. 2006, 46,118-124.

[32]. Trigo, G. G.; Martinez, M.; Galvez, E.J. Pharm. Sci. 1981, 70, 87-89.

[33]. Staudinger, H.; Niessen, G. Makromol. Chem. 1955, 15, 75-90.

[34]. Bellanato, J.; Galvez, E.; Espada, M.; Trigo, G. G. J. Mol. Struct. 1980, 67, 211-221.

[35]. Perez, J. A. G.; Gonzalez, M. A.; Requejo, J. L. J.; Albarran, J. C. P. Carbohydrate Res. 1983, 124, 15-17.

[36]. Frick, W.; Schmidt, R. R. Liebigs Ann. Chem. 1989, 6, 565-570

[37]. Schmidt(rk), R. R.; Frick, W. Tetrahedron 1988, 44, 7163-7169.

[38]. El-Desoky, E. S. I.; Abdel-Rahman, H. A. R.; Schmidt, R. R. Liebigs Ann. Chem. 1990, 9, 877-881.

[39]. Rashwan, O. A. Molecules 2002, 7, 75-80 